license

\title{
Implementasi E-Government Kulon Progo: Inovasi Dinas Kesehatan Melalui Aplikasi BumilKU 2019
}

Rico Kurniawan ${ }^{1}$, Muhammad Eko Atmojo ${ }^{2}$

richobarca.rf@gmail.com, atmojoeko91@gmail.com

12 Program Studi Ilmu Pemerintahan Universitas Muhammadiyah Yogyakarta

DOI http://dx.doi.org/10.22219/sospol.v6i2.11077

\begin{abstract}
Based on Indonesia committement on sustainable development, health improvement is a prominent issue. As an implementation of public service innovation, the Kulon Progo Regional Government through the Health Office plays a role in improving the quality of health services for pregnant women by creating the BumilKU application. Considering the importance of measuring the role of organizational performance on aspects of public service quality which refers to the e-government paradigm, this study aims to explain the performance of local governments in providing services to pregnant women through the BumilKU application. The data used in this study came from interviews, document studies, and literature studies related to research discussions. Based on several indicators of organizational performance measurement, pregnant women's health services utilize and use the BumilKU application effectively and efficiently. During the use of the application, the Health Office gets results according to the expected performance targets. Although the use of the BumilKU application did not significantly reduce the maternal mortality rate in 2019, based on the aspect of monitoring the condition of pregnant women in Kulon Progo, the performance of the Health Office has improved compared to the previous year. Services for pregnant women are carried out according to procedures and received good response from the community.
\end{abstract}

\begin{abstract}
Abstrak
Kualitas kesehatan menjadi isu strategis dalam komitmen pembangunan berkelanjutan Indonesia. Sebagai implementasi inovasi pelayanan publik, Pemerintah Daerah Kulon Progo melalui Dinas Kesehatan berperan meningkatkan kualitas pelayanan kesehatan ibu hamil dengan menciptakan aplikasi BumilKU. Mempertimbangkan pentingnya pengukuran peranan kinerja organisasi pada aspek kualitas layanan publik yang mengacu pada paradigma e-government maka penelitian ini bertujuan menjelaskan kinerja Pemerintah Daerah dalam memberikan pelayanan terhadap ibu hamil melalui aplikasi BumilKU. Data yang digunakan dalam penelitian ini bersumber hasil wawancara, studi dokumen, dan studi literatur untuk menjelaskan peran kinerja organisasi. Berdasarkan beberapa indikator pengukuran kinerja organisasi, pelayanan kesehatan ibu hamil memanfaatan dan menggunakan aplikasi BumilKU berjalan efektif dan efisien. Selama penggunaan aplikasi, Dinas Kesehatan memeroleh hasil sesuai target kinerja yang diharapkan. Walaupun penggunaan aplikasi BumilKU tidak membuat penurunan secara signifikan terhadap angka kematian ibu tahun 2019, akan tetapi berdasarkan aspek monitoring keadaan ibu hamil di Kulon Progo, kinerja Dinas Kesehatan mengalami kemajuan dibandingkan dengan tahun sebelumnya. Pelayanan terhadap ibu hamil dilaksanakan sesuai prosedur dan mendapat respon yang baik dari masyarakat.
\end{abstract}

\author{
Keywords \\ E-Government, \\ BumilKU, \\ Maternal Health, \\ Public Service \\ Innovation
}

\section{Article History}

Received January

22, 2020

Revised July 3,

2020

Accepted July 8, 2020

Published

October 13, 2020

\section{Corresponding \\ Author}

Rico Kurniawan. Program Studi

Ilmu

Pemerintahan

Universitas

Muhammadiyah

Yogyakarta. Jl.

Brawijaya,

Geblagan,

Tamantirto, Kec.

Kasihan, Bantul,

Daerah Istimewa

Yogyakarta 55183

\section{Pendahuluan}

Kesehatan menjadi hal yang fundamental dalam kehidupan dan menjadi isu strategis dalam pembangunan berkelanjutan. Anak-anak yang sehat dapat tumbuh dan berkembang dengan baik. Masyarakat yang sehat akan menjadi masyarakat produktif dan selanjutnya mampu mengangkat derajat kesejahteraannya. Sehingga dalam konteks tersebut kesehatan menjadi salah 
satu pondasi masyarakat untuk mengembangkan ekonomi, sosial, dan segala kegiatan yang menunjang kehidupan (Sachs \& Ban, 2015).

Dasar hukum terkait dengan kesehatan di Indonesia tertuang dalam UU No 36 Tahun 2009 memberikan gambaran terhadap tanggung jawab pemerintahan dalam meningkatkan kualitas kesehatan sebagai salah satu komponen utama dalam menciptakan kesejahteraan masyarakat. Undang-undang itu menjelaskan bahwa kesehatan merupakan hak setiap masyarakat Indonesia. Menjadi suatu kewajiban bagi warga negara untuk berpartisipasi dalam mewujudkan kesehatan di Indonesia dengan melaksanakan suatu mekanisme atau proses pelaksanaan kesehatan berdasarkan hak asasi manusia, sikap adil, berorientasi hasil, sesuai dengan tanggung jawab, keputusan yang benar, tidak membeda-bedakan jenis kelamin, melaksanakan suatu proses tanpa ada unsur pemaksaan dan tidak melanggar unsur-unsur nilai keagamaan (Sudarti \& Fauziah, 2014).

Berdasarkan WHO terdapat beberapa masalah kesehatan terbesar di Indonesia yang terdiri dari: Kesehatan Ibu dan Anak, TBC, Penyakit tidak menular, Kesehatan Mental, dan Cedera kepala karena kecelakaan. Dengan adanya beberapa maslah kesehatan yang menjadi perhatian lebih bagi setiap warga negara dan juga pemerintah untuk mewujudkan negara yang memiliki kualitas kesehatan tinggi. Lebih fokus lagi WHO mengatakan kematian ibu di berbagai negara disebabkan oleh pendarahan sebesar $27,1 \%$, masalah tekanan darah sebesar $14,0 \%$, persoalan sepsis sebesar $10 \%$, masalah abortus sebesar 7,9\%, persoalan emboli air ketuban sebesar 3,2\%, dan masalah infeksi lainnya sebesar 9,6\%. Sedangkan di Indonesia mengenai persoalan kematian ibu disebabkan oleh pendarahan yang menjadi penyebab utama dan memiliki persentase tertinggi (Sholikhah, Pradjatmo, \& Hakimi, 2016).

Salah satu aspek pelayanan kesehatan yang utama adalah terhadap ibu hamil. Perhatian pemerintah Indonesia terhadap ibu hamil telah tercantum dalam Peraturan Menteri Kesehatan Republik Indonesia Nomor 97 Tahun 2014 terkait dengan standar proses pelayanan terhadap kesehatan seorang ibu sebelum hamil, pada waktu hamil, pada proses melahirkan, dan pasca melahirkan. Permenkes tersebut menjelaskan betapa pentingnya menjamin kualitas pelayanan terhadap seorang ibu dalam melewati fase sebelum hamil, ketika hamil, proses melahirkan, dan pasca melahirkan. Selain itu, penting bagi lembaga pelayanan kesehatan untuk melaksanakan sosialisasi dan memberikan pengetahuan tentang proses kehamilan, melahirkan, pasca melahirkan, termasuk gizi seimbang dan upaya hidup sehat. Institusi yang berwenang juga wajib memberikan layanan dan fasilitas yang berkualitas yang memenuhi standar dalam proses persalinan seorang ibu (Handayani, Fitriani, \& Lestari, 2019). Dalam konteks kebijakan dan pelaksanaan pembangunan, pemerintah bertanggung jawab menjamin fasilitas dan terciptanya lingkungan yang mendukung keselamatan dan kesehatan ibu dan anak (Agustina \& Barokah, 2018).

Pemerintahan Kabupaten Kulon Progo yang sadar akan pentingnya faktor kesehatan dalam upaya mewujudkan tata kelola pemerintahan yang baik berbasis e-government. Pemda Kulon Progo menciptakan 10 website andalan, yang meliputi "Layanan Publik, Informasi Publik, Website OPD, Wisata, Layanan e-government, Layanan Aduan, Open Tata, Smart City, Desaku, Medsos". Pada website Layanan Publik dan Smart City terdapat aplikasi BumilKU di dalamnya yang menjadi unggulan di bidang kesehatan. Kesehatan menjadi salah satu titik fokus 
pemerintahan melalui Dinas Kesehatan Kulon Progo dengan mengutamakan kualitas pelayanan kesehatan salah satunya dengan menciptakan aplikasi BumilKU.

Adanya aplikasi BumilKU memberikan gambaran bahwa Pemerintahan yang merupakan organisasi publik memiliki kewajiban dalam pelayanan kesehatan yang ideal agar terciptanya kesejahteraan masyarakat dan terutama untuk meningkatkan pelayanan terhadap ibu hamil dalam upaya mengurangi jumlah kematian seorang ibu dan bayi baru lahir. Kualitas pelayanan kesehatan adalah tolak ukur kesempurnaan suatu pelaksanaan pelayanan kesehatan yang sesuai dengan standar profesi seseorang dan standar suatu pelayanan dengan memanfaatkan potensi sumber daya maupun fasilitas dengan maksimal. Memanfaatkan segala sesuatu sesuai dengan porsi dan manfaatnya yang tersedia di puskesmas atau rumah sakit secara efektif dan efisien dan tidak menyampingkan nilai-nilai etika, hukum, dan sosial budaya yang berlandaskan kinerja yang maksimal dalam pelayanan dan menjadikan kepuasan masyarakat yang paling utama. Kualitas suatu pelayanan akan tercipta dengan sebuah kinerja yang optimal dari pihak pelaksanaan atau yang memberikan suatu layanan bagi masyarakat (Ainurrahmah, 2017).

Menjadi suatu hakekat dan tanggung jawab bagi pegawai atau birokrat menjadi pelayan bagi publik dengan berorientasikan hasil yang mempermudah layanan bagi masyarakat. Hal tersebut diupayakan dengan menciptakan suatu proses pelayanan publik dengan beberapa teknologi yang berbasis internet dengan bertujuan mempermudah dalam memberikan layanan publik bagi masyarakat. Dengan kata sederhananya tujuan utama dari e-government adalah untuk meningkatkan layanan publik yang ideal dan berkualitas (Damanik \& Purwaningsih, 2017). Mengingat kinerja organisasi yang baik mengacu pada kinerja karyawan yang baik pula. Kinerja karyawan yang baik tidak terjadi secara otomatis begitu saja. Aspek-aspek seperti standar manajerial, pengetahuan dan keterampilan, komitmen dan penilaian kinerja dapat mempengaruhi kinerja karyawan. Untuk menilai, dapat menggunakan Penilaian Kinerja atau Performance Appraisal (PA) sebagai salah satu metode dalam melakukan tolak ukur (Wahyuningtyas \& Ratnasari, 2016). Suatu hal yang ideal akan berjalan sesuai dengan kenyataan kalau proses pelaksanaannya secara baik dan benar atau dengan kata lain dengan suatu kinerja yang optimal.

Berdasarkan Peraturan Bupati Kulon Progo No 87 Tahun 2013 terkait data dari Dinas secara Elektronik kepada Pemerintahan Daerah. Pemerintahan Kabupaten Kulon Progo melalui Dinas Kesehatan membuat suatu inovasi dengan membuat aplikasi BumilKU sebagai sarana memonitoring ibu hamil. Suatu aplikasi yang dimanfaatkan untuk meningkatkan kualitas layanan terhadap ibu hamil dan mencegah semua resiko-resiko kehamilan sehingga dapat memperkecil angka kematian ibu dan bayi baru lahir. Aplikasi BumilKU menjadi salah satu program unggulan yang diandalkan oleh Pemerintahan Kabupaten Kulon Progo yang berbasiskan data digital keseluruhan ibu hamil di Kabupaten Kulon Progo. Dinas kesehatan yang memiliki tanggung jawab atas meningkatkan layanan terhadap ibu hamil yang sangat terbantu atas adanya aplikasi BumilKU yang bisa memonitoring secara menyeluruh ibu hamil. Aplikasi BumiKU bisa menyeluruh desa- desa mengenai data ibu hamil dengan mengetahui secara rinci jumlah total ibu hamil, jumlah ibu hamil normal, jumlah ibu hamil resiko, ibu hamil resiko tinggi, dan HPL (hari perkiraan lahir) yang di-upgrade datanya setiap hari. Untuk proses pemantauan atau monitoring terhadap seluruh ibu hamil yang ada di Kabupaten Kulon Progo.

Aplikasi BumilKU yang menjadi salah satu program unggulan kesehatan terkhusus bagi ibu hamil dalam upaya mengurangi sacara optimal angka kematian ibu melahirkan dan bayi baru 
lahir di Kabupaten Kulon Progo. Mengoptimalkan suatu aplikasi dengan efektif dan efisien, sehingga suatu hal yang ideal berjalan dengan kenyataannya dalam proses pelaksanaannya. Suatu aplikasi BumiKU harus diimbangi dengan kinerja yang optimal dan maksimal dari Dinas Kesehatan ataupun stakeholder yang bersangkutan yakni bagi seluruh petugas atau pelayan dalam memberikan suatu layanan kesehatan bagi seluruh ibu hamil di Kulon Progo. Oleh karena itu penting untuk diteliti kinerja Dinas Kesehatan Kabupaten Kulon Progo dalam meningkatkan layanan ibu hamil dengan memanfaatkan aplikasi BumilKU tahun 2019.

\section{Peranan Kinerja Organisasi}

Kinerja (prestasi kerja) adalah sebuah hasil kerja dari segi kualitas dan kuantitas yang tercapai oleh seorang pegawai ketika menjalankan kewajibannya dengan berlandaskan memenuhi sebuah amanat yang telah diterimanya (Wahyuningtyas \& Ratnasari, 2016). Terdapat beberapa faktor yang mempengaruhi keberhasilan kinerja, seperti lingkungan kerja, fasilitas untuk kerja, kebiasaan dalam kerja, motivasi pegawai, dari segi kemampuan pegawai, struktur organisasi, kepemimpinan dalam memanajemen dan sebagainya (Sobirin, 2014). Kinerja merupakan istilah yang berasal dari kata 'job performance' atau 'actual performance' (prestasi kerja atau prestasi sesungguhnya yang dicapai seseorang). Kinerja merupakan implementasi dari rencana yang disusun. Implementasi kinerja dilakukan oleh sumber daya manusia yang memiliki kemampuan, kompetensi, motivasi dan kepentingan. Menurut (Abdurrahman, 2017) kinerja merupakan hasil pekerjaan yang mempunyai hubungan kuat dengan tujuan strategis organisasi dalam mencapai suatu tujuan atau dengan kata lain menjadikan suatu pencapaian sebuah hasil yang lebih baik dari suatu target yang diinginkan.

Penilaian kinerja merupakan proses di mana organisasi berupaya memperoleh informasi yang seakurat mungkin tentang kinerja para anggotanya. Sedangkan menurut Simamora penilaian kinerja (performance appraisal) adalah proses yang dipakai oleh perusahaan/organisasi untuk mengevaluasi pelaksanaan kerja Individu karyawan. Untuk lebih memperjelas bagaimana penilaian kinerja dalam sebuah organisasi untuk dapat menghasilkan individu-individu yang berkualitas dan kuantitas yang dihasilkan oleh karyawan (Abdurrahman, 2017). Sementara itu, menurut penilaian kinerja adalah seperangkat interaksi formal yang terstruktur antara bawahan dan atasan, biasanya dalam bentuk wawancara periodik, dimana kinerja bawahan ditinjau dan dibahas, dengan penekanan pada identifikasi kelemahan dan kekuatan serta sebagai peluang untuk perbaikan kinerja dan pengembangan keterampilan (Setiobudi, 2017).

Penilaian kinerja merupakan kajian sistematis tentang kondisi kerja karyawan yang dilaksanakan secara formal yang dikaitkan dengan standar kinerja yang yang telah ditentukan oleh perusahaan (Sari, Setiawan, \& Adilah, 2017). Dessler berpendapat bahwa penilaian kinerja adalah mengevaluasi dari seorang karyawan baik saat ini maupun di masa lalu dihubungkan dengan standar kinerja dari karyawan tersebut (Januari, Utami, \& Ruhana, 2015). Hasil penilaian kinerja dapat menunjukkan apakah SDM telah memenuhi tuntutan yang dikehendaki perusahaan, baik dilihat dari sisi kualitas maupun kuantitas. Terdapat beberapa faktor yang mempengaruhi proses penilaian kinerja, yaitu: Pertama, terdapatnya indikator penilaian kinerja, kriteria kinerja merupakan salah satu indikator utama yang menjadi titik fokus. Kriteria berdasarkan sifat, kriteria berdasarkan perilaku, dan kriteria berdasarkan hasil. Kedua, metode penilaian kinerja, metode penilaian kinerja harus mencakup lima hal, yaitu 
relevance (kesesuain hasil dan tujuan), acceptability (dapat diterima), reliability (dapat dipercaya), sensitivity (dapat membedakan hasil kerja), dan practically (meningkatkan produktivitas). Ketiga, terdapatnya penetapan penilai atau standar yang sangat erat hubungannya dengan persoalan apakah hasil penilaian obyektif atau tidak dalam menjalankan kinerja yang optimal dan berkualitas. Keempat, terjaminnya dari pelaksanaan Penilaian Kinerja yang ada, yakni pelaksanaan penilaian kinerja harus mencakup dua hal, yaitu: waktu pelaksanaan dan konteks penilaian (Abdurrahman, 2017).

Pengukuran kinerja adalah proses di mana organisasi menetapkan parameter hasil untuk dicapai oleh program, investasi, dan akuisisi yang dilakukan. Proses pengukuran kinerja sering kali membutuhkan penggunaan bukti statistik untuk menentukan tingkat kemajuan suatu organisasi dalam meraih tujuannya. Tujuan mendasar dibalik dilakukannya pengukuran adalah untuk meningkatkan kinerja secara umum (Sari et al., 2017). Lebih jauh, pengukuran kinerja adalah suatu alat manajemen untuk meningkatkan kualitas pengambilan keputusan dan akuntabilitas (Aniwati, 2014). Dengan demikian melalui pengukuran kinerja organisasi, dasar pengambilan keputusan yang masuk akal dapat dikembangkan dan dapat dipertanggung jawabkan oleh organisasi. Sedangkan menurut Dwiyanto menjelaskan dalam pengukuran kinerja ada beberapa indikator yang digunakan untuk mengukur kinerja birokrasi publik, yaitu: Pertama, produktivitas, yaitu tidak hanya mengukur tingkat efisiensi, tetapi juga mengukur efektivitas pelayanan. Produktivitas pada umumnya dipahami sebagai rasio antara input dengan output. Kedua, kualitas layanan, menjadi suatu hal yang sangat penting untuk memberikan rasa kepuasan bagi seluruh masyarakat dengan suatu proses pelaksanaan yang mempermudah (Aditama \& Widowati, 2017). Mempertimbangkan pentingnya pengukuran peranan kinerja organisasi pada aspek kualitas layanan publik yang mengacu pada paradigma $e$ government maka penelitian ini bertujuan menjelaskan kinerja Pemerintah Daerah dalam memberikan pelayanan terhadap ibu hamil melalui aplikasi BumilKU.

\section{Metode}

Penelitian ini menggunakan metode kualitatif yang bertujuan mendeskripsikan implementasi tata kelola pemerintah daerah yang baik melalui studi kasus Kabupaten Kulon Progo. Kebijakan Pemkab melaksanakan konsep e-government ditunjukkan dengan inovasi kinerja Dinas Kesehatan melalui pemanfaatan aplikasi BumilKu sebagai objek penelitian.

Data yang digunakan dalam penelitian ini bersumber dari data primer hasil wawancara dan data sekunder dari studi literatur beberapa dokumen dan publikasi penelitian terkait dengan pembahasan topik. Pengumpulan data dengan wawancara yang menggunakan teknik purposive sampling dalam menentukan narasumber. Teknik ini dipilih karena peneliti memilih informan berdasarkan tujuan dan pertimbangan tertentu, dan dengan menentukan kriteria-kriteria yang sesuai kebutuhan. Pemilihan informan atas dasar apa yang diketahui tentang elemen-elemen yang dibutuhkan sebagai data wawancara, meliputi, Kepala Dinas Kesehatan Kabupaten Kulon Progo, Kepala Bidang Kesehatan Masyarakat, Kepala Seksi Kesehatan Keluarga dan Gizi, Bidan Kepala Bidang Kesehatan Ibu dan Anak (KIA), Kader Kesehatan, dan ibu hamil yang ada di Desa Bendungan, dan Ngestiharjo, Kulon Progo. 
license

\section{Hasil dan Pembahasan}

\section{Kematian Ibu dan Bayi Sebagai Masalah Kesehatan di Kulon Progo}

Salah satu upaya untuk mempercepat penurunan Angka Kematian Ibu (AKI) dan Angka Kematian Bayi (AKB), Dinas Kesehatan memanfaatkan aplikasi BumilKU sebagai aplikasi momonitoring seluruh ibu hamil di Kulon Progo dan dilanjutkan dengan kualitas pelayanan bagi ibu hamil. Adanya aplikasi BumilKU menjadi inovasi pemerintah daerah dalam rangka meningkatkan derajat kesehatan masyarakat. Mengingat AKI dan AKB di Indonesia disebabkan karena kurangnya pelayanan, fasilitas, ataupun pengetahuan masyarakat (Wulandari, 2017). Dengan demikian, strategif mempercepat penurunan AKI dan AKB penting dilaksanakan di setiap daerah, provinsi, kabupaten/kota dengan program kesehatan ibu dan anak sebagai perhatian khusus.

\section{Grafik 1. Jumlah Kematian Ibu Hamil Kabupaten Kulon Progo tahun 2015-2019}

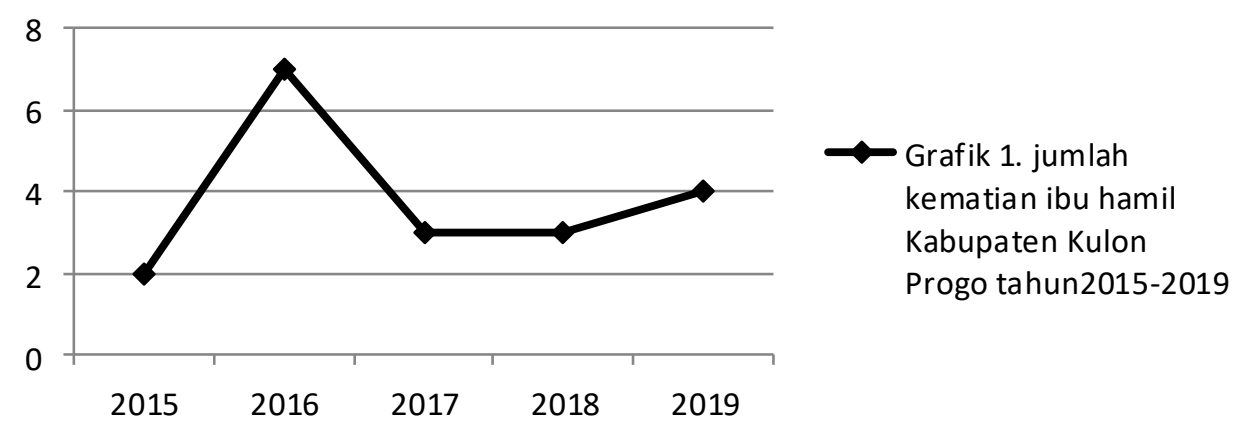

Sumber: Dinas Kesehatan Kulon Progo, 2019

Salah satu upaya pemerintah yaitu Pemerintahan Kabupaten Kulon Progo, khususnya Dinas Kesehatan Kabupaten Kulon Progo berlandaskan dengan peraturan dan perintah dari pemerintahan daerah berkoordinasi dengan Dinas Komunikasi dan Informasi Kulon Progo membuat sebuah aplikasi di penghujung tahun 2018, yakni aplikasi BumilKU yang mana Dinas Kesehatan Kulon Progo sebagai pengguna dan penanggung jawab utama dari aplikasi ini. Dengan adanya aplikasi BumilKU tersebut Pemerintahan Kabupaten Kulon Progo dan Dinas Kesehatan Kulon Progo dapat menurunan angka kematian ibu khususnya di Kabupaten Kulon Progo. Hal ini medidukung oleh penelitian (Chasanah, 2015) di mana peran pemerintah dalam aspek inovasi perlu dilakukan karena hal ini akan memberikan keterbukaan pikiran masyarakat tentang AKB dan AKI. Lebih jauh, dibutuhkan peran dari kader masyarakat untuk dapat mensosialisasikan kepada masyarakat.

Berdasarkan Grafik 1, jumlah kematian ibu di Kabupaten Kulon Progo dalam kurun waktu 2015-2019 terlihat fluktuatif. Pada tahun 2015 terdapat 2 kasus, namun pada tahun 2016 mengalami peningkatan 5 kasus. Pada tahun 2017 jumlah kematian ibu kembali menurun yaitu menjadi 3 kasus, terjadi di Kecamatan Panjatan (2 orang) dan seorang berasal dari Kecamatan Sentolo. Pada tahun 2018 jumlah kematian ibu ada 3 kasus, terjadi di Kecamatan Wates, Galur dan Nanggulan. Pada penghujung tahun 2019 sementara jumlah kematian ibu ada 4 kasus. Hasil 
data ini berlandaskan dengan kematian perempuan pada saat hamil atau kematian dalam kurun waktu 42 hari sejak terminasi kehamilan tanpa memandang lamanya kehamilan, yakni kematian yang disebabkan karena kehamilannya atau penanganannya, tetapi bukan karena sebab-sebab lain seperti kecelakaan dan terjatuh.

Berdasarkan Grafik 2, Angka Kematian Bayi (AKB) meski belum stabil, cenderung menurun dalam kurun waktu 5 tahun. Pada tahun 2015 sebesar 48 bayi kelahiran hidup, pada tahun 2015 sedikit mengalami kenaikan sebesar 49 bayi kelahiran hidup. Sedangkan di tahun 2016 kembali menghasilkan penurunan yang begitu baik sebanyak 42 bayi kelahiran hidup, meskipun kembali mengalami sedikit kenaikan pada tahun 2018 sebesar 43 bayi kelahiran hidup. Pada tahun 2019 mengalami penurunan yang cukup signifikan yakni sebesar 26 bayi kelahiran hidup, meskipun masih akan ada kemungkinan penambahan jumlah di penghujung tahun. Angka kematian bayi sebagai gambaran terkait masalah kesehatan bayi dengan penyebabpenyebab yang dapat mempengaruhi terhadap kesehatan bayi berupa gizi dari bayi, penyakit infeksi terhadap bayi, dan kecelakaan bayi.

Grafik 2. Angka Kematian Bayi (AKB)

Kabupaten Kulon Progo tahun 2015-2019

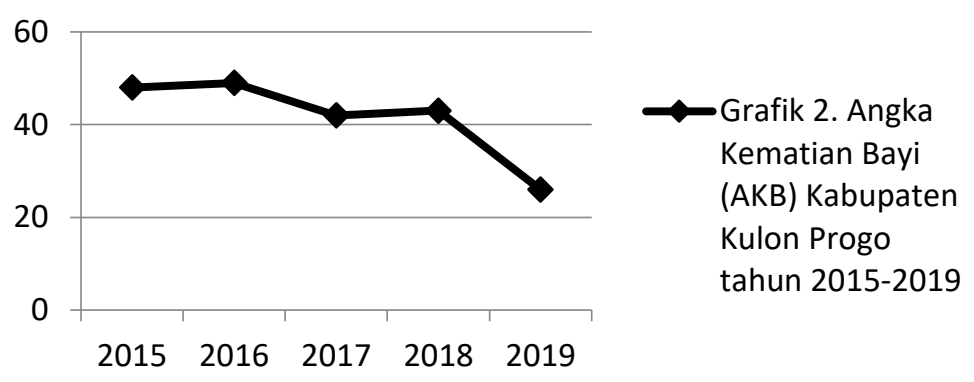

Sumber: Dinas Kesehatan Kulon Progo (2019)

Berdasarkan Tabel 1 dan Tabel 2 jumlah kematian seorang ibu dan bayi yang baru dilahirkan di Kabupaten Kulon Progo berada pada angka yang cukup rendah akan tetapi belum stabil untuk mengurangi secara maksimal. Berdasarkan sebuah data pada tabel 1 yang terdapat di aplikasi BumilKU per tanggal 25-12-2019 Kabupaten Kulon Progo terdapat Angka Total BumilKU sebanyak 1921 bumil, angka yang Normal sebanyak 1355 bumil, angka yang Risiko sebanyak 412, angka yang Risiko Tinggi sebanyak 154 bumil, dan angka Hari Perkiraan Lahir (HPL) sebanyak 6 bumil. Data yang mendapatkan angka total yang terdiri dari seluruh ibu hamil di Kabupaten Kulon Progo yang terdapat di 12 Kecamatan. Data terkait angka total ibu hamil ditiap Kecematan meliputi dari Kecamatan Temon sebanyak 114 bumil, Kecamatan Wates sebanyak 428 bumil, Kecamatan Panjatan sebanyak 196 bumil, Kecamatan Galur sebanyak 135 bumil, Kecamatan Lendah sebanyak 178 bumil, Kecamatan Sentolo sebanyak 156 bumil, Kecamatan Pengasih sebanyak 186 bumil, Kecamatan Kokap sebanyak 96 bumil, Kecamatan Girimulyo sebanyak 77 bumil, Kecamatan Nanggulan sebanyak 125 bumil, Kecamatan Samigaluh sebanyak 104 bumil, Kecamatan Kalibawang sebanyak 126 bumil.

Dinas Kesehatan Kabupaten Kulon Progo merupakan salah satu lembaga yang mengemban tugas pelaksanaan menjamin kualitas pelayanan ibu hamil dengan memanfaatkan 
license

apliaksi BumilKU yang dapat memonitoring keseluruhan ibu hamil di Kulon Progo. Adapun untuk mengukur keberhasilan kinerja Dinas Kesehatan Kabupaten Kulon Progo dalam upaya meningkatkan layanan ibu hamil dengan memanfaatkan aplikasi BumilKU, digunakan beberapa indikator pengukuran kinerja, yaitu melalui terpenuhnya unsur produktivitas dan unsur kualitas pelayanan.

Tabel 1. Jumlah Bumil dan Status Kehamilan Bumil dari 12 Kecamatan di Kabupaten Kulon Progo per tanggal 25-12-2019

\begin{tabular}{|c|l|c|c|c|c|}
\hline \multirow{2}{*}{ No } & \multirow{2}{*}{ Kecamatan } & Normal & Risiko & $\begin{array}{c}\text { Risiko } \\
\text { Tinggi }\end{array}$ & (HPL) \\
\cline { 3 - 6 } & & 80 bumil & 25 bumil & 9 bumil & 0 bumil \\
\hline 1 & Temon & 339 bumil & 67 bumil & 22 bumil & 1 bumil \\
\hline 2 & Wates & 123 bumil & 49 bumil & 24 bumil & 0 bumil \\
\hline 3 & Panjatan & 84 bumil & 43 bumil & 8 bumil & 1 bumil \\
\hline 4 & Galur & 114 bumil & 45 bumil & 19 bumil & 1 bumil \\
\hline 5 & Lendah & 116 bumil & 21 bumil & 19 bumil & 0 bumil \\
\hline 6 & Sentelo & 131 bumil & 44 bumil & 11 bumil & 1 bumil \\
\hline 7 & Pengasih & 61 bumil & 30 bumil & 5 bumil & 1 bumil \\
\hline 8 & Kokap & 46 bumil & 21 bumil & 10 bumil & 0 bumil \\
\hline 9 & Girimulyo & 98 bumil & 18 bumil & 9 bumil & 0 bumil \\
\hline 10 & Nanggulan & 77 bumil & 21 bumil & 6 bumil & 0 bumil \\
\hline 11 & Samigaluh & 86 bumil & 28 bumil & 12 bumil & 1 bumil \\
\hline 12 & Kalibawang & Sumber: aplikasi BumilkU, 2019 &
\end{tabular}

Tabel 2. Angka kematian Ibu dan Angka Kematian Bayi (AKB) di Kulon Progo tahun 2015-2019

\begin{tabular}{|c|c|c|}
\hline Tahun & Angka Kematian Ibu & Angka Kematian Bayi \\
\hline 2015 & 2 orang & 48 bayi \\
\hline 2016 & 7 orang & 49 bayi \\
\hline 2017 & 3 orang & 42 bayi \\
\hline 2018 & 3 orang & 43 bayi \\
\hline 2019 & 4 orang (sementara) & 26 bayi (sementara) \\
\hline
\end{tabular}

Sumber: Dinas Kesehatan Kulon Progo tahun 2019

\section{Unsur Produktivitas Dalam Peningkatan Kinerja Pelayanan Ibu Hamil}

Untuk meningkatkan kualitas pelayanan, Aplikasi BumilKU (ibu hamil Kulon Progo) merupakan aplikasi pemantauan kesehatan ibu hamil yang mengintegrasikan Nomor Induk Kependudukan (NIK) dan geospasial. BumilKu menggunakan NIK (Nomor Induk Kependudukan) dan geospasial untuk menyesuaikan layanan kesehatan terdekat dari ibu hamil di Kulon Progo ketika harus memperoleh penanganan kehamilan. Resiko bahaya kehamilan yang tinggi berhasil diatasi dengan aplikasi berbasis website. Data ibu hamil yang terikat dengan lokasi koordinat geospasial memudahkan pemerintah mendapatkan informasi mengenai waktu melahirkan, usia ibu hamil, usia janin, dan tingkat resiko kehamilan yang muncul sebagai notifikasi. Terjaminnya sebuah status kehamilan seorang ibu dengan sistem pemantauan dengan menggunakan aplikasi BumilKu. Berdasarkan hasil wawancara didapatkan bahwa aplikasi Bumilku merupakan aplikasi yang sangat membantu bagi pendataan ibu hami diwilayah Kabupaten Kulon Progo. Pendataan ini dilakukan dengan adanya koordinasi antara Pemerintah Kabupaten sampai dengan tingkat yang paling bawah yaitu bidan desa. Adapun data yang 
diperlukan adalah NIK, domisili, nomor telfon, titik lokasi rumah. Hal tersebut harus diisi oleh masyarakat khususnya ibu-ibu hamil (Kadinkes, 2019).

Penyajian data dalam aplikasi BumilKU berasal dari pendaftaran ibu hamil kepada kader kesehatan dengan mengisi biodata berbasis NIK, Alamat Domisili/lokasi ibu hamil, Nomor Telepon/Ponsel, Pointing rumah/GIS. Terkait pemantauan dari bidan desa/pembantu degan mengecek terkait golongan darah, terkait Hari Perkiraan Lahir (HPL), Riwayat kehamilan ( $G, P, A)$, dan jaminan yang beriringan dengan monev fasilitas kesehatan oleh bidan puskesmas atau dokter puskesmas dengan mengisi diagnosa, mengisi ANC (k1-k4), memberikan ACN terpadu, dan memberikan Status. Standar pelayanan bagi kelas penanganan persalinan ibu hamil (rumah bersalin, puskesmas, dan RSUD) dibagi menjadi 3 (tiga) tingkatan. Jenis persalinan normal ditangani oleh bidan, persalinan dengan resiko ditangani di Puskesmas, dan jika persalinan beresiko tinggi ditangani di RSUD. Adanya aplikasi tersebut juga sangat membantu dalam hal pelayanan publik, terutama untuk meningkatakan kualitas pelayanan pulik di Dinas Kesehatan Kabuapten Kulon Progo (Kadinkes, 2019).

Secara garis besar, strategi kinerja peningkatan kualitas pelayanan kepada ibu hamil berbasis inovasi aplikasi BumilKU meliputi; (1) Tersedianya data ibu hamil, ibu bersalin ibu nifas dan bayi dapat tampilan aplikasi BumilKU. Tenaga lapangan lebih mudah menyajikan data yang akurat, karena adanya pemantauan dan surpervisi secara berjenjang dan terintegrasi dengan NIK memudahkan dan mempercepat kerja petugas lapangan karena aplikasi dapat dioperasionalkan secara mobile akan proses input data. Sehingga terlaksananya pelayan kesehatan dalam menolong persalinan sesuai standar seperti yang telah di tetapkan sesuai kelas dalam aplikasi BumilKU yang meliputi ibu hamil normal, ibu hamil resiko, dan ibu hamil resiko tinggi kemudian pelayan kesehatan memberikan pelayanan nifas sesuai standar. (2) Tidak ada keterlambatan dalam merujuk dan rujukan sesuai kompetensi fasilitas kesehatan. Dikarenakan dengan memanfaatkan aplikasi BumilKU yang mengetahui titik posisi ibu hamil, diiringi dengan dimonitoring oleh pihak Dinas Kesehatan dan para pelayan kesehatan bagi penanganan bagi ibu hamil. Penyediaan kualitas data meningkatkan akurasinya, tidak seperti sebelumnya dengan google drive laporan sulit dilakukan konfirmasi kebenarannya dan saling checking antar stakebolders akan meningkatkan kualitas data yang lebih valid dengan data realtime dapat diakses 24 jam secara online. Terpantaunya kasus ibu hamil untuk menekan resiko tinggi bagi ibu hamil, ibu bersalin ibu nifas dan bayi. Layanan ibu hamil, ibu bersalin ibu nifas dan bayi kegawat daruratan. Lebih lanjut, untuk dapat memberikan komunikasi yang baik dalam penurunan kasus kematian ibu dan anak, perlu juga adanya koordinasi antar stakeholder, melakukan regulasi serta kerta adanya kerjasama dnegan mitra, hal ini juga akan berdampak pada peningkatan kualitas pelayanan (Sofiah, Hapsari, \& Sumardiyono, 2016).

Berdasarkan hasil wawancara dengan Kepala Dinas Kesehatan bahwa Dinkes mempunyai peran yang sangat penting diantaranya adalah mensosialisasikan kepada masyarakat, melakukan monitoring dan evaluasi, sampai dengan rekapitulasi data (Kadinkes, 2019). Peran Dinas Kesehatan Kabupaten Kulon Progo dalam upaya meningkatkan layanan ibu hamil dengan aplikasi BumilKU dilaksanakan dengan tahapan; (1) Melakukan sosialisasi terkait aplikasi BumilKU, baik kepada instansi di bawahnya yaitu Puskesmas, maupun peran seperti bidan/bidan pembantu, kader kesehatan hingga masyarakat, (2) Memonitoring dan mengevaluasi setiap kegiatan terkait program dan kegiatan, (3) Memantau perjalanan atau tahapan 
setiap kegiatan program dalam pelayanan ibu hamil, (4) Melakukan rekapitulasi data dan analisa laporan dari seluruh Puskesmas wilayah Kulon Progo dan laporan pelayanan kesehatan Ibu baik dari Rumah Sakit Pemerintah maupun Rumah Sakit Swasta, (5) Mengevaluasi dari sebuah kegiatan suatu program.

Berdasarkan hasil wawancara Bidan Desa dan Kader Kesehatan mempunyai peran yang sangat sentral dalam mensukseskan pelayanan publik, terutama dalam implementasi aplikasi Bumilku. Bidan desa selalu melakukan deteksi dan kontroling terhadap ibu-ibu hamil, selain itu kader kesehatan juga mempunya peran yang sentral dalam hal pendataan ibu-ibu hamil disetiap dusun (Bidan Desa dan Kader Kesehatan, 2019). Dalam rangka meningkatkan kualitas layanan ibu hamil dengan memaksimalkan peran dari seorang bidan dan kader kesehatan tingkat desa di Kabupaten Kulon Progo, Dinas Kesehatan Kulon Progo mendukung optimalisasi kerja sama instansi terkait.

1) Peran Puskesmas (Bidan Puskesmas)

Puskesmas yang menjadi salah Unit Pelaksana Teknis Dinas Kesehatan Kulon Progo berperan penting memberikan suatu layanan atau penanganan yang berkualitas bagi ibu hamil. Pihak puskesmas tetap selalu terkoordinasi oleh Dinas Kesehatan supaya menjalankan fungsi dan tugas secara maksimal dalam memberikan layanan bagi ibu hamil di Kulon Progo. Pihak Dinas Kesehatan Kulon Progo yang melibatkan bidan puskesmas tingkat kecamatan dan bidan bantu yang berperan penting dalam menggunakan aplikasi BumilKU yang berisikan data realtime terkait ibu hamil. Bidan tingkat kecamatan yang akan memberikan data terkait ibu hamil yang menggambarkan status ibu hamil dengan klas ibu hamil normal, ibu hamil resiko, ibu hamil resiko tinggi, dan hari perkiraan melahirkan untuk disajikan dalam aplikasi BumilKU.

Pihak puskesmas harus memenuhi tugas-tugas seperti berikut. Pertama, mengumpulkan data terkait ibu hamil dari setiap bidan pembantu dan kader kesehatan. Kedua, menentukan target sasaran dan memastikan ketersediaan logistik bagi setiap ibu hamil untuk keberlangsungan layanan ibu hamil dan memantau pelaksanaan layanan ibu hamil tingkat desa dengan melakukan supervisi fasilitatif terhadap bidan. Ketiga, mengadakan pertemuan rutin sebagai forum kerja sama yang baik untuk mendiskusikan masukan-masukan dari masyarakat ataupun menyelesaikan masalah terkait layanan ibu hamil yang beriringan dengan melakukan pemeriksaan ibu hamil sesuai standar minimal 4 kali selama masa kehamilan. Keempat, melakukan penyuluhan dan konseling pada ibu hamil beserta keluarga mengenai kehamilan, persalinan, dan gaya hidup sehat serta melakukan kunjungan rumah dengan salah satu bentuk layanan ibu hamil. Kelima, memberikan pertolongan persalinan sesuai standar dan memberikan pelayanan nifas sesuai dengan standar. Kelima, membuat pencatatan dan membuat laporan terkait ibu hamil di Kulon Progo. Pelaksanaan yang dilaksanakan dari tiap Puskesmas di Kabupaten Kulon Progo yang berjumlah sebanyak 21 Puskesmas yang terdiri 6 Puskesmas dengan tempat tidur (Puskesmas Sentolo I, Temon I, Galur II, Samigaluh II, Girimulyo II, dan Puskesmas Panjatan II) dan 15 Puskesmas non tempat tidur. Dua puskesmas non tempat tidur diantaranya dilengkapi dengan rumah bersalin yaitu Puskesmas Lendah I dan Panjatan I. Jumlah Puskesmas Pembantu yang ada sebanyak 63 buah yang tersebar di seluruh Kabupaten Kulon Progo. Terdapat 21 buah jumlah dari Puskesmas Keliling. Menjadi salah satu unit pelaksana kesehatan yang membantu menjalankan sebuah program kesehatan oleh Dinas Kesehatan di Kabupaten Kulon Progo. 
license

\section{2) Peran Kader Kesehatan}

Kader kesehatan berperan penting dalam pelayanan tingkat rendah untuk terlaksana hingga pelayanan jenjang yang tinggi langsung terhubung dengan Dinas Kesehatan (Chasanah, 2015). Tidak terlepas dari Dinas Kesehatan Kulon Progo yang memiliki 21 puskesmas yang ada di 12 kecamatan di Kulon Progo sebagai unit pemberi pelayanan ibu hamil yang diberikan wewenang bagi tiap-tiap puskesmas untuk berinovasi dalam upaya peningkatan layanan bagi ibu hamil. Puskesmas Wates yang merupakan memberikan terobosan salah satunya dengan membuat kader-kader kesehatan di 8 desa dan skala kecilnya lagi di tiap dusun-dusun per desa yang ada di Kecamatan Wates.

Kader kesehatan yang ada tiap desa dan bahkan tingkat tiap dusun yang ada di Kulon Prog melakukan pertemuan rutin dengan difasilitasi oleh bidan dari puskesmas kecamatan. Kemudian Kader kesehatan membantu peran Bidan, Puskesmas, dan Dinas Kesehatan Kulon Progo dalam mendata ibu hamil dari tingkat terendah atau tingkat desa dan Melakukan pendataan secara rutin (bulanan) mengenai KIA. Sebagai kader kesehatan menjadi suatu motivasi bagi masyarakat umum agar mau berpartisipasi terhadap program atau kegiatan bagi layanan ibu hamil seperti posyandu dan poswindu yang dilakukan oleh bidan.

\section{Unsur Kualitas dalam Peningkatan Kinerja Pelayanan Ibu Hamil}

Kualitas pelayanan publik merupakan salah satu hal terpenting dalam menjalankan kinerja organisasi publik. Pandangan negatif selalu bermunculan ketika masyarakat menilai suatu kualitas pelayanan. Hal demikian terjadi bahwa banyak rasa ketidakpuasan masyarakat terhadap layanan yang diberikan suatu organisasi publik. Untuk itu ada baiknya sebelum memberikan pelayanan kepada masyarakat, hendaknya setiap pemangku tugas pelaksana mengetahui terlebih dahulu bagaimana peran, tugas, dan wewenang yang perlu dilakukan ketika terjun di masyarakat.

Dinas Kesehatan Kulon Progo yang mempertegaskan terkait layanan dengan adanya suatu perizinan pagi pelaksana layanan untuk memberikan layanan ataupun sebuah memberikan praktek kesehatan yang menjadi unit pelaksana kesehatan sebagai salah satu pengguna aplikasi BumilKU. Perlunya perizinan dari pihak Dinas Kesehatan dalam upaya terciptanya layanan yang berkualitas, seperti halnya perizinan bagi tugas/praktek dokter, perizinan tugas/praktek perawat, dan perizinan tugas/praktek bidan di Kabupaten Kulon Progo. Dalam hal ini, pembinaan juga perlu dilakukan bagi pelaksana pelayanan terhadap Kesehatan Ibu dan Anak, karena hal ini mempengaruhi tingkat kepercayaan masyarakat terhadap pelayanan yang diberikan (AS, Mahsyar, \& Malik, 2020).

Dinas Kesehatan Pemerintahan Kulon Progo beserta unit pelaksana pelayanan kesehatan selalu berupaya untuk mewujudkan layanan yang berkualitas bagi ibu hamil dengan menekankan terhadap pelayanan yang efektif dan efisien, akan tetapi tidak melupakan hal yang mendasar dalam memberikan suatu pelayanan yakni pelayanan yang beretika sesuai pola perilaku baik dari pegawai dalam memberikan pelayanan. Secara sederhananya Dinas Kesehatan dan pelayan kesehatan di Kulon Progo memegang teguh prinsip bahwa mereka pelayan publik yang melayani bukan malah dilayani oleh publik, suatu hal yang menjadi tanggung jawab yang berorientasikan kepada kepuasan masyarakat/ibu hamil di Kulon Progo. Bentuk suatu pelayanan yang di bawah pantauan dari Dinas Kesehatan Kulon Progo dan selalu melakukan evaluasi 
untuk membenahi suatu program dan kegiatan dalam upaya meningkatkan layanan ibu hamil di Kulon Progo. Salah satu terobosan utama yang diberikan ialah dengan adanya aplikasi BumilKU untuk memonitoring seluruh ibu hamil di Kulon Progo pada tahun 2019.

Pemanfaatan aplikasi dan kualitas layanan kinerja Dinas Kesehatan Kulon Progo sudah cukup baik dalam melaksanakan program kegiatan dengan pemantauan bagi tiap pelaksana atau petugas kesehatan di Kulon Progo. Pihak yang berperan terutama Dinas Kesehatan Kabupaten Kulon Progo sebagai pemantau utama terus menjalankan program kegiatan dengan memanfaatkan aplikasi BumilKU tersebut sesuai dengan prosedur dan pertanggung jawabannya atas wewenang dan ranahnya. Dalam upaya meningkatkan kualitas layanan ibu hamil pihak Dinas Kesehatan Kulon Progo berlandaskan nilai transparansi atau keterbukaaan dalam memberikan layanan, nilai akuntabilitas atau pertanggung jawaban dari suatu layanan, nilai kondisional atau layanan yang bisa menyesuaikan berbagai kondisi dan keadaan, nilai partisipatif atau mendengarkan aspirasi rakyat.

Dengan adanya aplikasi BumilKU pihak Dinas Kesehatan selalu memonitoring seluruh ibu hamil dan mengkoordinasikan dengan pegawai kesehatan atau piha-pihak yang terlibat dalam layanan ibu hamil dengan program RINDU KIA. Pihak Dinas Kesehatan yang selalu memberikan seperti halnya rujukan bagi ibu-ibu hamil yang beresiko. Prosedur dan tahap-tahap yang ditekankan dalam pemanfaatan aplikasi BumilKU dalam proses pelaksanaan layanan bagi ibu hamil di Kulon Progo meliputi; (1) Mendata seluruh ibu hamil atau tahap pendaftran ibu hamil yang berisikan biodata berbasis NIK ibu hamil, Alamat Domisili/lokasi ibu hamil, Nomor Telp/hp, dan Pointing rumah/GIS. Tahap pemantauan oleh bidan desa atau pembantu dalam mengechek gol darah ibu hamil, terkait Hari Perkiraan Lahir (HPL),kejelasan Riwayat kehamilan (G,P,A), dan memberikan suatu jaminan; (2) Tahap Monev fasilitas kesehatan bidan puskesmas wilayah terkait dengan sebuah diagnosa, terkait ANC sebuah kunjungan (k1-k4), lalu ACN terpadu, dan memberikan status dan keterangan bagi keadaan kehamilan seorang ibu. Sehingga terciptanya mekanisme persalinan ibu hamil jika melahirkan Normal boleh degan bidan tetapi tidak boleh dilakukan di rumah ibu hamil itu sendiri, kalau status kehamilan ibu dengan resiko disarankan melakukan persalinan di Puskesmas, dan jika status kehamilan ibu Resiko tinggi di laksanakan persalinan di RSUD.

Sedangkan penekanan dari Dinas Kesehatan kepada petugas kesehatan atau pihak-pihak dalam memberikan layanan ibu hamil di Kulon Progo memenuhi pelayanan dasar meliputi: (1) Cakupan kunjungan ibu hamil (K1-K4). Pelayanan antenatal adalah pelayanan oleh tenaga professional (dokter spesialis kebidanan, dokter umum, bidan, dan tenaga kesehatan) untuk ibu selama masa kehamilannya dengan melakukan ukur tinggi badan, ukur tekanan darah, pemberian immunisasi TT, ukur tinggi fundus uteri, dan pemberian tablet besi minimal 90 tablet selama masa kehamilan. Cakupan K1 dapat dipantau melalui pelayanan kunjungan baru ibu hamil (K1) untuk mengukur akses dan pelayanan ibu hamil sesuai standar untuk melihat kualitas. Ibu hamil yang mendapatkan pelayanan antenatal sesuai standar paling sedikit empat kali, dengan distribusi pemberian pelayanan yang dianjurkan adalah minimal satu kali pada trimester pertama, satu kali pada trimester kedua dan dua kali pada trimester ketiga umur kehamilan; (2) Cakupan Komplikasi Kebidanan yang Ditangani. Komplikasi kebidanan adalah kesakitan pada ibu hamil, ibu bersalin, ibu nifas yang dapat mengancam jiwa ibu dan/atau bayi. Penanganan komplikasi kebidanan adalah ibu hamil, bersalin dan nifas dengan komplikasi yang mendapatkan pelayanan 
sesuai standar pada tingkat pelayanan dasar dan rujukan mencakup Polindes, Puskesmas, Puskesmas PONED (Pelayanan Obstetri Neonatus Esensial Dasar), Rumah bersalin, RSIA/RSB, RSU, dan RSU PONEK (Pelayanan Obstetri Neonatus Emergensi Komprehensif); (3) Cakupan Pertolongan Persalinan oleh Tenaga Kesehatan. Persalinan diupayakan oleh bidan atau tenaga kesehatan dengan kompetensi kebidanan. Cakupan persalinan yang ditolong oleh tenaga kesehatan yang cakupannya sudah per wilayah. Kesiapan dan kecepan tanggapan dari tenaga kesehatan dalam melaksanakan proses persalinan bagi ibu hamil di Kulon Progo; (4) Cakupan Pelayanan Nifas. Pelayanan ibu nifas sesuai standar adalah pelayanan kepada ibu nifas sedikitnya 3 kali, kunjungan nifas ke-1 pada 6 jam setelah persalinan s.d 3 hari; kunjungan nifas ke-2 hari ke 4 s/d hari ke 28 setelah persalinan, kunjungan nifas ke-3 hari ke 29 s/d hari ke 42 setelah persalinan.

\section{Kesimpulan}

Keberhasilan kinerja Dinas Kesehatan Kabupaten Kulon Progo dalam upaya meningkatkan kualitas layanan ibu hamil dengan aplikasi BumilKU di Kulon Progo digunakan beberapa indikator pengukuran kinerja, yaitu melalui faktor Produktivitas dan faktor Kualitas Pelayanan dengan memanfaatkan dan menggunakan aplikasi BumilKU. Terlihat dari pemanfaatan dan penggunaan aplikasi BumilKU dilihat dari faktor produktivitas maka dapat disimpulkan bahwa Kinerja Dinas Kesehatan Kabupaten Kulon Progo telah efektif dan efisien. Hal tersebut dapat dilihat dari hasil yang diperoleh atau output yang didapatkan selama penggunaan aplikasi BumilKU ini berlangsung bahwa target atau sasaran telah sesuai dengan apa yang diharapkan, meskipun dengan adanya penggunaan aplikasi BumilKU tidak membuat penurunan secara signifikan terhadap angka kematian ibu di tahun 2019 di Kulon Progo, akan tetapi mengalami kemajuan yang lebih baik dibandingkan dengan tahun sebelumnya dari segi memonitoring seluruh keadaan ibu hamil di Kulon Progo. Kemudian faktor Kualitas Pelayanan terlihat dari, kualitas pelayanan bagi ibu hamil setelah penggunaan aplikasi BumilKU secara garis besarnya sudah efektif dan efisien. Kinerja Dinas Kesehatan Kabupaten Kulon Progo sudah efektif dan efisien, karena kualitas pelayanan yang diberikan sudah sesuai dengan prosedur dan masyarakat pun menanggapi dengan respon yang baik.

\section{Referensi}

Abdurrahman, J. (2017). Faktor yang Mempengaruhi Evaluasi Kinerja Para Pegawai di Kantor Pemerintahan. PIONIR, Jurnal Pendidikan, 6(1), 151-165. Retrieved from https://jurnal.ar-raniry.ac.id/index.php/Pionir/article/view/3366/2358

Aditama, P. B., \& Widowati, N. (2017). Analisis Kinerja Organisasi Pada Kantor Kecamatan Blora. Journal of Public Policy and Management Review, 6(2). https://doi.org/https://doi.org/10.14710/jppmr.v6i2.15994

Agustina, S. A., \& Barokah, L. (2018). Determinan Berat Badan Lahir Rendah (BBLR). Jurnal Kebidanan, $\quad 8$ (November),
https://www.researchgate.net/publication/333451392_DETERMINAN_BERAT_BA
DAN_LAHIR_RENDAH_BBLR

Ainurrahmah, Y. (2017). Pengaruh Manajemen Pusat Kesehatan Masyarakat terhadap Akses Pelayanan Kesehatan untuk Mewujudkan Mutu Pelayanan Kesehatan. Jurnal Publik, 
11(2), 239-256. Retrieved from https://journal.uniga.ac.id/index.php/JPB/article/view/177/168

Aniwati, A. (2014). Evaluasi Kinerja Pegawai dalam Pelayanan Publik di Kantor Kecamatan Busang Sangatta Kabupaten Kutai Timur. EJurnal Ilmu Administrasi Negara, 2(4), 18521865. Retrieved from https:// ejournal.ap.fisip-unmul.ac.id/site/?p=1169

AS, A., Mahsyar, A., \& Malik, I. (2020). Implementasi Kebijakan Kesehatan Masyarakat Dalam Upaya Menurunkan Angka Kematian Ibu Dan Bayi ( Studi Kasus Di Kabupaten Bulukumba Dan Takalar). Journal of Public Policy and Management, 1(1), 22-28. https://doi.org/https://doi.org/10.26618/jppm.v1i1.2579

Chasanah, S. U. (2015). Peran Petugas Kesehatan Masyarakat dalam Upaya Penurunan Angka Kematian Ibu Pasca MDGs 2015. Jurnal Kesehatan Masyarakat Andalas, 9(2), 73-79. https://doi.org/10.24893/jkma.v9i2.190

Damanik, M. P., \& Purwaningsih, E. H. (2017). E-Government dan Aplikasinya di Lingkungan Pemerintah Daerah. Jurnal Studi Komunikasi Dan Media, 21(2), 151-164. Retrieved from https://jurnal.kominfo.go.id/index.php/jskm/article/view/210202/697

Handayani, F., Fitriani, H., \& Lestari, C. I. (2019). Hubungan Umur Ibu dan Paritas dengan Kejadian BBLR di Wilayah Puskesmas Wates Kabupaten Kulon Progo. Midwifery Journal, $\quad 4(2), \quad 67-70 . \quad$ Retrieved from http://journal.ummat.ac.id/index.php/MJ/article/view/808/848

Januari, C. I., Utami, H. N., \& Ruhana, I. (2015). Pengaruh Penilaian Kinerja Terhadap Kepuasan Kerja dan Prestasi Kerja (Studi pada Karyawan PT. Telekomunikasi Indonesia, Tbk Wilayah Malang ). Jurnal Administrasi Bisnis, 24(2), 1-8. Retrieved from http://administrasibisnis.studentjournal.ub.ac.id/index.php/jab/article/view/968/1150

Moleong, L. J. (2012). Metodologi Penelitian Kualitatif. Bandung: PT. Remaja Rosdakarya.

Sachs, J. D., \& Ban, K. (2015). The Age of Sustainable Development. In The Age of Sustainable Development. https://doi.org/10.7312/sach17314

Sari, E. P., Setiawan, S., \& Adilah, A. R. (2017). Analisis Penilaian Kinerja Organisasi Perangkat Daerah Di Kota Bandung (Studi Kasus Pada Dinas Pemakaman \& Pertamanan; Dinas Kependudukan \& Pencatatan Sipil dan Dinas Pemuda dan Olahraga). Jurnal Akutansi Maranatha, 9 (November), https://doi.org/https://doi.org/10.28932/jam.v9i2.483

Setiobudi, E. (2017). Analisis Sistem Penilaian Kinerja Karyawan Studi pada PT. Tridharma Kencana. Journal of Applied Business and Economics, 3(3), 170-182.

Sholikhah, S., Pradjatmo, H., \& Hakimi, M. (2016). Kepatuhan bidan Puskesmas dalam Penerapan Antenatal Care Terpadu Berkualitas, Deteksi Penyakit dan Komplikasi pada Ibu Hamil. Berita Kedokteran Masyarakat, 32(5).

Sobirin, A. (2014). Konsep Dasar Kinerja dan Manajemen Kinerja. In Managemen Kinerja (pp. 167). Universitas Terbuka.

Sofiah, S., Hapsari, S. K., \& Sumardiyono, S. (2016). Pencegahan Kematian Ibu dan Anak melalui Pendekatan Strategi Komunikasi pada Program EMAS (Expanding Maternal and Neonatal Survival). Jurnal Ilmu Komunikasi, 14(3), 165-174. Retrieved from http://jurnal.upnyk.ac.id/index.php/komunikasi/article/view/2129

Sudarti, S., \& Fauziah, A. (2014). Hubungan Tingkat Pengetahuan Ibu Hamil Tentang ANC 
dengan Frekuensi Kunjungan ANC di BPS Fajar Samiati, Yogoyudan, wates, Kulon Progo, Yogyakarta. Jurnal Medika Respati, 9(2), 36-51. Retrieved from https:/ / docplayer.info/61690701-Hubungan-tingkat-pengetahuan-ibu-hamil-tentanganc-dengan-frekuensi-kunjungan-anc-di-bps-fajar-samiati-yogoyudan-wates-kulonprogo-yogyakarta.html

Wahyuningtyas, D., \& Ratnasari, K. (2016). Analisis Pengaruh Motivasi Kerja Terhadap Kinerja Karyawan DI Anggrek Spa Jakarta. 315-327.

Wulandari, D. A. (2017). Responsivitas dinas Kesehatan Kabupaten dalam Upaya Menurunkan Angka Kematian Ibu (AKI) dan Angka Kematian Bayi (AKB) di Kabupaten Karanganyar (Universitas Sebelas Maret). Retrieved from https://eprints.uns.ac.id/39621/1/d0113025_pendahuluan.pdf

\section{Wawancara}

Bidan Desa. (2019). Desa Karangwuni, Kecamatan Wates, Kabupaten Kulon Progo, 4 September 2019.

Kader Kesehatan Kecamatan Wates. (2019). Desa Karangwuni, Kecamatan Wates, Kabupaten Kulon Progo, 21 Agustus 2019.

Kepala Dinas Kesehatan Kabupaten Kulon Progo. (2019). Kantor Dinas Kesehatan Kabupaten Kulon Progo, 7 Agustus 2019. 